\title{
The SYSTEMATIC POSITION OF The GENUS FOSSARINA, A. ADAMS ANd ANGAS, AND of FOSSARINA VARIA, HUTTON.
}

\author{
By H. Leighton Kesteven.
}

\section{Part I.- The Genus Fossarina.}

Some time ago I found that F'ossarina patula, Adams and Angas, had a rhipidoglossate dentition and a multispiral operculum. I mentioned the discovery to Mr. Hedley, and he at once drew my attention to the genus Minos, Hutton, and gave me dried specimens of the type (M. petterdi, Crosse), and of Fossarina varia, Hutton. The examination of these has been productive of rather curious results.

The genus Fossarina was described by A. Adams and Angas in $1863,{ }^{1}$ their type being $F$. patula, from Sydney Harbour. A short description of the shell is followed by the statement, "Operculum corneum, subspirale," and "this genus constitutes a peculiar littoral form allied to Fossar, from which it differs in the curvature of the inner lip and circular aperture." It is also compared with Conradia, A. Ad., and Isapis, A. Ad., and here I might draw the attention of those more fortunately placed than myself, to the fact that none of the six species of the former of these two genera have been figured. When dealing with the Japanese species (Fossarina picta, A. Ad.), ${ }^{2}$ Dunker questioned the correctness of the systematic assignment of the species. ${ }^{3}$

Stearns and Pilsbry, when recording the same species, placed it between Littorina and Echinella, removing it from the family Fossaridæ. ${ }^{4}$

The statement of Adams and Angas that the operculum was subspiral has proved disastrous. Hutton obtained specimens of Fossarina petterdi, Crosse, ${ }^{5}$ to compare with his $F$. varia, and found that it had a multispiral operculum and a dentition like Cantharidus, ${ }^{6}$ and in 1885 made the genus Minos for its reception. ${ }^{7}$

1 A. Adams and Angas-Proc. Zool Soc., 1863, p. 423, pl. xxxvii , f. 9, 10.

2 A. Adams-Proc. Zool. Soc., 1867, p. 312, pl. xix., f. 26.

3 Dunker-Mar. Moll. Jap., i., 1882, p. 113.

4 Stearns and Pilsbry-Cat. Mar. Moll. Jap., 1895, p. 52.

5 Crosse-Journ. de Conch., (3), ×., 1870, p. 303; (3), xi., 1871, p. 323, pl. xii., f. 1.

6 Hutton-Proc. Linn. Soc. N.S.W., vii., 1883, p. 66.

7 Hutton-Loc. cit., ix., 1884 (1885), p. 369. 